\title{
Preliminary Phytochemical Analysis and Biological Evaluation of Four Medicinal Chinese Plant Extracts against Tribolium castaneum
}

(Analisis Fitokimia Awal dan Penilaian Biologi pada Empat Ekstrak Tumbuhan Ubatan Cina terhadap Tribolium castaneum)

\author{
Mokhtar Mohamedalamin Mokhtar, Jianfeng Li, Zhiping Du \& FAngQin ChenG*
}

\section{ABSTRACT}

Application of botanical pesticides is a new trend in pest control nowadays as an environmentally safe alternative measures for synthetic chemicals. Hence, this study was aimed to analyze the phytochemical constituents of four medicinal Chinese plants, namely Lonicera maackii, Platycladus orientalis, Viburnum opulus, and Crataegus pinnatifida, and to investigate the insecticidal potentialities of leaves extracts of these plants against Tribolium castaneum. The research was carried out under laboratory conditions, at the Institute of Resources and Environmental Engineering, Shanxi University, China. Ethyl acetate, methanol and water extracts of the plant leaves were tested at different concentrations $(5,2.5$, and $1.25 \% \mathrm{w} / \mathrm{v})$. Yields of extracting materials, mortality and repellent effects were the important parameters evaluated. The phytochemical screening showed the presence of alkaloids, saponins, tannins, flavonoid, and terpenoids in C. pinnatifida, but the other plants contain some of these compounds. The highest ethyl acetate extract concentration (5\%) of $\mathrm{V}$. opulus and $\mathrm{C}$. pinnatifida obtained the best mortality means (5.00 \pm 0.41 and $4.75 \pm 0.25 a$, respectively), compared to the other treatments, but without significant differences from the middle concentration (2.5\%) of both extracts. In repellency test, L. maackii methanol achieved the highest repellency percentage (91.38\%). The findings proved that ethyl acetate extract of $\mathrm{V}$. opulus and $\mathrm{C}$. pinnatifida are the best insecticidal treatment, whereas methanol extract of $\mathrm{L}$. maackii is the best repellent effect, against $\mathrm{T}$. castaneum. These three plants require additional studies to be assessed as a component in pest management of store pests.

Keywords: Chinese plants; methanol extract; repellent effect; Tribolium castaneum

ABSTRAK

Penggunaan racun perosak botani merupakan trend terbaru pada masa kini dalam kawalan perosak sebagai langkah alternatif yang selamat untuk alam sekitar bagi bahan kimia sintetik. Oleh itu, kajian ini bertujuan untuk menganalisis juzuk fitokimia daripada empat tumbuhan ubatan Cina iaitu Lonicera maackii, Platycladus orientalis, Viburnum opulus dan Crataegus pinnatifida dan untuk mengkaji potensi racun serangga daripada ekstrak daun tumbuhantumbuhan ini terhadap Tribolium castaneum. Penyelidikan ini dijalankan di makmal Institut Sumber dan Kejuruteraan Alam Sekitar, Universiti Shanxi, China. Ekstrak etil asetat, metanol dan air daripada daun tumbuhan diuji pada kepekatan yang berbeza (5, 2.5 dan 1.25\% w/v). Hasil daripada pengekstrakan bahan, kematian dan kesan penghalau adalah antara parameter penting yang dinilai. Pemeriksaan fitokimia telah menunjukkan adanya alkaloid, saponin, tanin, flavonoid dan terpenoid pada C. pinnatifida, tetapi tumbuhan lain juga mengandungi sebilangan sebatian ini. Kepekatan ekstrak etil asetat tertinggi (5\%) pada V. opulus dan C. pinnatifida memperoleh kaedah kematian terbaik (masing-masing $5.00 \pm 0.41$ dan $4.75 \pm 0.25$ a), berbanding dengan rawatan lain, tetapi tanpa perbezaan yang signifikan untuk kepekatan lain (2.5\%) bagi kedua-dua ekstrak. Dalam ujian penghalauan, metanol bagi L. maackii memberi peratusan penghalauan tertinggi (91.38\%). Hasil kajian membuktikan bahawa ekstrak etil asetat V. opulus dan C. pinnatifida adalah rawatan racun serangga terbaik, manakala ekstrak metanol bagi L. maackii memberikan kesan penghalau yang terbaik terhadap T. castaneum. Ketiga-tiga tanaman ini memerlukan kajian tambahan untuk dinilai sebagai komponen dalam pengurusan perosak bagi perosak stor.

Kata kunci: Ekstrak metanol; kesan penghalau; Tribolium castaneum; tumbuhan cina 


\section{INTRODUCTION}

Insects have emerged on the surface of the earth more than 400 million years ago (El Minshawy \& Hegazi 2001). The majority of insects are very useful to human and the environment; some insects are parasitoids or predators on other harmful pests such as Amphibulus venator (Klug) prey on Tribolium castaneum, some are pollinators, for example, honey bees and moths, others help for organic matter decomposition or produce important products like honey or silk and some produce medicinal substances venoms or antibodies, for instance (Seufi \& Galal 2019; Shaheen et al. 2016). However, less than 0.5 percentage of insect species are harmful insects (pests), and only three orders: Coleoptera, Lepidoptera, and Psocoptera contain species that are considered as major pests of stored products (Meyer 2020; Sallam 1999).

Pests of stored products are currently divided into primary and secondary pests. Primary pests which able to attack whole, unbroken grains, for example, lesser grain borer (Rhyzopertha dominica), granary weevil (Sitophilus granarius), rice weevil (Sitophilus oryzae) and Angoumois grain moth (Sitotroga cerealella). Secondary pests attack only damaged grain, milled products and dust such as red flour beetle (Tribolium castaneum), confused flour beetle (Tribolium confusum), sawtoothed grain beetle (Oryzaephilus surinamensis) and Indian meal moth (Plodia interpunctella) (Emery \& Cousins 2019; Nayak \& Daglish 2018). Among these insects, the red flour beetle (Tribolium castaneum Herbst) is considered an important secondary pest feeds of flour, dried fruits, nuts and broken grains. It causes the damage by the adult and larvae and excretes toxic quinones which pollute flour and its products (Sallam 1999; Via 1999). The fumigation pesticides such as Phosphine the main method to control T. castaneum (Agrafioti et al. 2019). However, the widespread use of synthetic pesticides has significant drawbacks including development of strains resistant to insecticides (White 1995; Zettler \& Cuperus 1990), increased costs, handling hazards, concerns about insecticides residues on grains, and threats to human being health, animals and the different components of the environment (Noling \& Becker 1994; Taylor 1994).

These cited and other problems of synthetic pesticides, has become necessary to find alternative methods of control such as agricultural, physical, and biological controls. Among these methods botanical extracts are considered a new trend for controlling and numerous botanical extracts were investigated against many kinds of stored grain pests (Dhaniya \& Dayanandan
2016; Priya et al. 2016; Satti \& Elamin 2012; Waliullah et al. 2014).

In China, there are about 7000 species of medicinal plants used in Traditional Chinese Medicine, most of them are not toxic and contain many chemical compounds (Chen et al. 2017; Sasidharan et al. 2011; WHO 1997). Therefore, this research aimed to determine the presence of alkaloids, saponins, tannins, flavonoid, and terpenoids for leaves extracts of four medicinal Chinese plants, namely Amur Honeysuckle (Lonicera maackii Maximowicz), Oriental Arborvitae (Platycladus orientalis (L.) Franco), European Cranberry bush (Viburnum opulus L.) and Chinese Hawthorn (Crataegus pinnatifida Bunge) and to investigate the biological activities (insecticidal and repellent effect) of these plants against Tribolium castaneum, to find plants strong insecticidal to control the pest.

\section{MATERIALS AND METHODS}

\section{PLANT MATERIAL}

The studied plants, viz., L. maackii, P. orientalis, $V$. opulus, and $C$. pinnatifida were identified by Professor Zhiping Du, Institute of Resources and Environmental Engineering, Shanxi University, Taiyuan, Shanxi, China. Leaves of these plants were collected from an area around Shanxi University and brought to the laboratory. They were dried in the shade and crushed into fine powders using an electric blender and kept in jars until being extracted.

\section{PREPARATION OF BOTANICAL EXTRACTS}

Three extracts were prepared from the leaves namely, ethyl acetate, methanol, and water extracts. For organic extracts, two solvents (ethyl acetate and methanol) were utilized to extract the studied plant samples in a Soxhlet apparatus. The extraction started with the ethyl acetate to get the intermediate polarity compounds, a weight of $20 \mathrm{~g}$ leaves powder from each plant sample was put inside the Soxhlet thimble and extracted by $250 \mathrm{~mL}$ of the solvent for $9 \mathrm{~h}$ at $60^{\circ} \mathrm{C}$. Thereafter, the solvent was vaporized from the extracted materials by normal air in the laboratory; the extraction was repeated several times with new samples to procure the required quantity. Correspondingly, the extracted samples were dried and re-extracted successively at $55^{\circ} \mathrm{C}$ using the methanol to obtain the polar compounds, in the same way. The extracted materials were put in dark bottles $(250 \mathrm{~mL})$ and placed in a refrigerator until 
used. However, the samples were re-weighed after each extraction process to assess the percentages of the extracted. Regarding the preparation of concentrations of organic extracts $5 \mathrm{~g}$ of each organic extract were diluted with $95 \mathrm{~mL}$ of water to get the highest concentration (5\%) for this study. The 2.5 and $1.25 \%$ concentrations were prepared through serial dilutions (Elamin \& Satti 2013). As regards, the water extracts were prepared before one day of the experiment. The required powders of plant samples were weighted in a conical flask $(100 \mathrm{~mL})$ and $50 \mathrm{~mL}$ of water was added, the mixture was stirred using a magnetic mixer for $30 \mathrm{~min}$ and left to stand overnight. In the experiment day, the extract was re-stirred before filtration by filter paper and diluted with $50 \mathrm{~mL}$ of water to obtain the highest concentration (5\%). Thereupon, the lowest concentrations (2.5 and 1.25\%) were prepared by serial dilutions with water.

\section{THE CULTURE OF T. castaneum}

T. castaneum was online purchased by Tao Bao (Chinese program for online shopping) and identified in College of Life Sciences, Shanxi University. The insects were introduced in glass jars $(1200 \mathrm{~mL})$; wheat flour was sterilized at $60^{\circ} \mathrm{C}$ for $60 \mathrm{~min}$ and put inside the glass jars as feed for insects. Thereafter, the glass jars were covered with gauze, pasted by sticky tape to secure insects from the escape and placed in the incubator at $30 \pm 2{ }^{\circ} \mathrm{C}$ and $65 \pm 8 \%$ R.H. Insects from these cultures were used in the experiment (Bilal et al. 2015; Mishra et al. 2016; Zia et al. 2011).

\section{PHYTOCHEMICAL ANALYSIS}

Preliminary phytochemical screening to determine the presence of alkaloids, saponins, tannins, flavonoid, and terpenoids were carried out based on the previous studies (Banu \& Cathrine 2015; Kumar et al. 2007; Parekh \& Chanda 2007; Selvakumar \& Madhan 2017).

\section{MORTALITY EFFECT}

The experiment to investigate the mortality effect was executed during July, 2018. Each $20 \mathrm{~g}$ of wheat grids were immersed in $20 \mathrm{~mL}$ with one of the botanical extracts concentrations for $5 \mathrm{~min}$ and dried at $35^{\circ} \mathrm{C}$ for $60 \mathrm{~min}$ then placed into a test tube. Ten adults of T. castaneum were introduced in each test tube and replaced in the incubator. Accordingly, four replications were used according to Completely Randomized design and evaluation of the test tubes was performed regularly on $2^{\text {nd }}, 4^{\text {th }}, 6^{\text {th }}, 8^{\text {th }}$, $10^{\text {th }}, 14^{\text {th }}$, and $21^{\text {st }}$ days following treatments. Therefore, the mortality of insects was recorded and analyzed using ANOVA analysis, if significant differences were found at $\mathrm{P}<0.05$ level Duncan's Multiple Range Test was used. However, the Tukey's test was utilized for comparison means of extracted materials and repellency test (at $\mathrm{p}=$ 0.05), with SPSS version 16 (Ebadollahi 2011).

\section{REPELLENCY TEST}

In this experiment, only the $5 \%$ concentration of the studied plant extracts was tested against $T$. castaneum. Locally made repellency equipment was designed according to Berndt (1963) with a little difference; the central platform was expanded to a Petri dish. Before treatment with the extracts, wheat grinds were distributed irregularly in the peripheral holes of the repellency equipment, including the control. A number of $200 \mathrm{~T}$. castaneum were placed in a Petri dish and located in the central hole of the platform. On the second day ( $24 \mathrm{~h})$, the numbers of insects were calculated for each peripheral hole and recorded, the experiment was repeated in the third and fourth days to take three counts (Elamin \& Satti 2012). Accordingly, the obtained data were analyzed to calculate the repellency or attractancy activities of each extract according to Leonard and Ehrman (1976) formula: $\mathrm{A}=\frac{N o-N b}{N t}$

where $\mathrm{A}$ is attractancy $(+)$ or repellency (-); No is number of insects in the test hole; $\mathrm{Nb}$ is number of insects in the control hole; and $\mathrm{Nt}$ is the total number of insects in both holes. The output of this equation ranges from -1 (100 repellent) to $+1(100 \%$ attractant $)$ when compared to the control.

\section{RESULTS AND DISCUSSION}

\section{EXTRACTION YIELDS OF PLANT SAMPLE}

The mean quantity and percentage extracted of extraction yields of the studied plant samples are presented in Table 1. It is clear that the methanol extract of $P$. orientalis and $C$. pinnatifida reflected the highest percentages yields (18.55 and 18.5\%) of all samples. On the other hand, L. maackii ethyl acetate extract scored the lowest percentage yields (5.50\%). In all tested plants, methanol extracts higher yields than ethyl acetate extract. The result is consistent with those reported by Elamin and Satti (2013) who observed that methanol extract of 
desert date (Balanites aegyptiaca) leaves obtained higher extracted materials $(25.8 \%)$ than ethyl acetate extract (11.6). Our result suggests that the content of polar materials in testing plants were higher than the intermediate polarity compounds. Nevertheless, ethyl acetate extracts of some plants were recorded higher mortality rates than those obtained by methanol extracts. This proved that a quantity of extracting materials is not always the factor governing their insecticidal activity, but the types and chemical characteristics of such materials seem to be important.

TABLE 1. The mean weight (g) and percentage of extracted materials from leaves of the studied plants, using organic solvents (ethyl acetate and methanol)

\begin{tabular}{lcc}
\hline \multicolumn{1}{c}{ Plant samples } & Extracted materials per $20 \mathrm{~g}$ \\
\cline { 2 - 3 } & $( \pm$ S.E. $)$ & $(\%)$ \\
\hline L. maackii ethyl acetate extract & $1.10 \pm 0.03 \mathrm{f}$ & 05.50 \\
L. maackii methanol extract & $3.39 \pm 0.02 \mathrm{bc}$ & 16.95 \\
P. orientalis ethyl acetate extract & $3.06 \pm 0.03 \mathrm{~d}$ & 15.30 \\
P. orientalis methanol extract & $3.71 \pm 0.11 \mathrm{a}$ & 18.55 \\
V. opulus ethyl acetate extract & $3.18 \pm 0.02 \mathrm{~cd}$ & 15.90 \\
V. opulus methanol extract & $3.48 \pm 0.09 \mathrm{ab}$ & 17.40 \\
C. pinnatifida ethyl acetate extract & $1.43 \pm 0.00 \mathrm{e}$ & 07.15 \\
C. pinnatifida methanol extract & $3.70 \pm 0.05 \mathrm{a}$ & 18.50 \\
\hline
\end{tabular}

*Means followed by same letters are not significantly different from each other according to Tukey's test at $\mathrm{P}<0.05$ level

\section{PHYTOCHEMICAL ANALYSIS}

The results of chemical analysis for the studied plants are shown in Table 2. The five tested chemical groups were detected in the botanical extracts, but at variable levels based on the plant and the extract type. All the tested extracts contained saponins except L. maackii and C. pinnatifida water extracts and methanol extract of the former. On the contrary, no alkaloids were detected in the extracts except $V$. opulus and $C$. pinnatifida ethyl acetate extracts. On the other hand, all extracts of $L$. maackii contained flavonoids and $C$. pinnatifida contained tannins. In general, $C$. pinnatifida contains all tested chemical groups; V. opulus contains alkaloids, saponins and terpeniods; $P$. orientalis contains tannins, flavonoids and saponins, and L. maackii contains saponins and flavonoids. This result agreed with many previous studies which reported that $C$. pinnatifida leaves contain many chemical compounds such as monoterpene, lignan glycosides, sesquiterpene, flavonoids, diterpenoid, flavanone, triterpenoid and hydroxycinnamic acids (Chu et al. 2019; Gao et al. 2010; Shi et al. 2018; Song et al. 2011). Regarding V. opulus, the ethyl acetate fraction of the leaves and bark of the plant contain various biologically active compounds including phenolic acids, tannins, hydroxybenzoic acids, coumarins, alkaloid, phenol, coumarin, and steroids (Adebayo et al. 2017). Similarly, the preliminary phytochemical analysis of $P$. orientalis leaves extracts (ethyl acetate:chloroform:ethanol 
(40:30:30) and methanol:distilled water (70:30)) showed the presence of many compounds such as tannins, saponins, flavonoids (Jasuja et al. 2013).

TABLE 2. Preliminary phytochemical analysis of ethyl acetate, methanol and water extracts of L. maackii, P. orientalis, V. opulus, and C. pinnatifida

\begin{tabular}{|c|c|c|c|c|c|}
\hline Sample & Alkaloids & Saponins & Tannins & Terpenoids & Flavonoids \\
\hline L. maackii ethyl acetate extract & - & - & - & - & + \\
\hline L. maackii methanol extract & - & - & - & - & + \\
\hline L. maackii water extract & - & + & - & - & + \\
\hline P. orientalis ethyl acetate extract & - & + & - & - & - \\
\hline P. orientalis methanol extract & - & + & - & - & + \\
\hline P. orientalis water extract & - & + & + & - & + \\
\hline V. opulus ethyl acetate extract & + & + & - & - & - \\
\hline V. opulus methanol extract & - & + & - & - & - \\
\hline V. opulus water extract & - & + & - & + & - \\
\hline C. pinnatifida ethyl acetate extract & + & + & + & - & - \\
\hline C. pinnatifida methanol extract & - & + & + & - & - \\
\hline C. pinnatifida water extract & - & - & + & + & + \\
\hline
\end{tabular}

$+=$ Present; $-=$ Absent

\section{INSECTICIDAL ACTIVITIES OF TREATMENTS}

All extracts of $L$. maackii and $P$. orientalis were very low in mortality means for the pest; ranges between 0.00 and 0.50 from the commencement of the experiment until the end (21 days), no significant differences were found between treatments and the control. Accordingly, this result indicated that plant extracts do not have insecticidal activities for this pest. This may be due to either leaves extract of L. maackii and P. orientalis contain chemical compounds not toxic for the test insect or have repellent and/or antifeeding effects, prevent insects to close in on the treatments for feeding. The findings are similar to previous result (Cipollini et al. 2008) who reported that leaves of L. maackii contain phenolic compounds (apigenin and chlorogenic) not have biological effects against Spodoptera exigua Hubner. Moreover, the $P$. orientalis has repellent actions as reported by Dwivedi and Shekhawat (2004). On the other hand, L. maackii was reported to act as herbicide. According to Miller and Gorchov (2004), L. maackii shrubs reduce growth and final size for some of perennial herbs such as Allium burdickii, Thalictrum thalictroides, and Viola pubescens. Dorning and Cipollini (2006) observed that aqueous extracts of the L. maackii (leaves and roots) reduced seeds germination 
of Impatiens capensis, Alliaria petiolata, and Arabidopsis thaliana. Similarly, P. orientalis has antibacterial and antifungal activities (Alinezhad et al. 2011; Duhan et al. 2013; Manimegalai et al. 2010; Sati et al. 2014).

Table 3 shows the result of insecticidal effects of European Cranberry bush ( $V$. opulus) and Chinese Hawthorn ( $C$. pinnatifida) leaves extracts on the adult of T. castaneum. After 6 days, the $C$. pinnatifida ethyl acetate extract $(5 \%)$ secured the highest significant mortality means and continued the best treatment until the $10^{\text {th }}$ day of the experiment. In this interval ( $10^{\text {th }}$ day), $2.5 \%$ concentration of $C$. pinnatifida and $5 \%$ of $V$. opulus of ethyl acetate extracts obtained significant results. From 14 days onwards, all tested botanical extracts reflected significant mortality means compared with the control, except all methanol extracts of both plants.

The highest mortality means were achieved by $5 \%$ ethyl acetate of both plants, followed by $2.5 \%$ of them, without significant difference between them. In general, the best mortality means were scored by 5 and $2.5 \%$ ethyl acetate extracts of both plants. This result is similar to what was recorded by Alam et al. (2012) who verified the insecticidal effect of Viburnum grandiflorum stem extract and its ethyl acetate fraction against T. castaneum, Callosbruchus analis, and Rhyzopertha dominica. The insecticidal activity may be resulted from a quality of active compounds of these extracts compared with the other extracts. These plants were reported to contain active compounds like flavonoids, alkaloids which have good insecticidal activity (Castillo-Sánchez et al. 2010; Regnault-Roger et al. 2004). According to Adebayo et al. (2017), V. opulus leaves contain several active compounds such as alkaloid, phenol and steroids. Considering the C. pinnatifida, more than 150 compounds including: flavonoids, triterpenoids, steroids, monoterpenoids, sesquiterponoids, lignans, hydroxycinnamic acids, organic acids and nitrogen-containing compounds have been isolated and identified from $C$. pinnatifida (Wen et al. 2017; Wu et al. 2014). On the other hand, most of those compounds may be intermediate polarity compounds, so the methanol extracts obtained the lowest mortality means.

TABLE 3. Mortality mean of red flour beetle (Tribolium castaneum) fed on wheat grind treated with European Cranberry bush

(Viburnum opulus) and Chinese Hawthorn (Crataegus pinnatifida) leaves organic and water extracts, during July 2018

\begin{tabular}{|c|c|c|c|c|c|}
\hline \multirow[t]{2}{*}{ Treatment } & \multicolumn{5}{|c|}{ Mortality mean $( \pm$ S.E. $)$ at different intervals } \\
\hline & 6 days & 8 days & 10 days & 14 days & 21 days \\
\hline V. op. eth.ac. ext. $5 \%$ & $0.50 \pm 0.29 b$ & $0.75 \pm 0.25 b c$ & $1.50 \pm 0.29 \mathrm{bc}$ & $3.50 \pm 0.29 \mathrm{a}$ & $5.00 \pm 0.41 \mathrm{a}$ \\
\hline V. op. eth.ac. ext. $2.5 \%$ & $0.50 \pm 0.29 b$ & $0.75 \pm 0.25 b c$ & $1.00 \pm 0.41 \mathrm{bcd}$ & $2.25 \pm 0.25 \mathrm{bc}$ & $4.25 \pm 0.25 \mathrm{ab}$ \\
\hline V. op. eth.ac. ext. $1.25 \%$ & $0.25 \pm 0.25 b$ & $0.50 \pm 0.29 b c$ & $1.00 \pm 0.41 \mathrm{bcd}$ & $1.50 \pm 0.50 \mathrm{cde}$ & $2.25 \pm 0.25 \mathrm{cde}$ \\
\hline V. op. meth. ext. $5 \%$ & $0.50 \pm 0.29 b$ & $0.50 \pm 0.29 \mathrm{bc}$ & $0.75 \pm 0.48 \mathrm{bcd}$ & $0.75 \pm 0.48 \mathrm{defg}$ & $0.75 \pm 0.48 \mathrm{fgh}$ \\
\hline V. op. meth. ext. $2.5 \%$ & $0.25 \pm 0.25 b$ & $0.25 \pm 0.25 b c$ & $0.25 \pm 0.25 \mathrm{~cd}$ & $0.25 \pm 0.25$ fg & $0.25 \pm 0.25 \mathrm{gh}$ \\
\hline V. op. meth. ext. $1.25 \%$ & $0.25 \pm 0.25 b$ & $0.25 \pm 0.25 b c$ & $0.25 \pm 0.25 \mathrm{~cd}$ & $0.25 \pm 0.48 \mathrm{fg}$ & $0.25 \pm 0.25 \mathrm{gh}$ \\
\hline V. op. water ext. $5 \%$ & $0.25 \pm 0.25 b$ & $0.50 \pm 0.29 b c$ & $1.00 \pm 0.41 \mathrm{bcd}$ & $1.50 \pm 0.29 \mathrm{cde}$ & $4.00 \pm 0.41 \mathrm{ab}$ \\
\hline V. op. water ext. $2.5 \%$ & $0.00 \pm 0.00 \mathrm{~b}$ & $0.25 \pm 0.25 b c$ & $0.75 \pm 0.25 \mathrm{bcd}$ & $2.00 \pm 0.41 b c$ & $3.25 \pm 0.25 b c$ \\
\hline V. op. water ext. $1.25 \%$ & $0.00 \pm 0.00 \mathrm{~b}$ & $0.00 \pm 0.00 \mathrm{c}$ & $0.00 \pm 0.00 \mathrm{~d}$ & $1.25 \pm 0.25 \mathrm{cdef}$ & $2.50 \pm 0.29 \mathrm{~cd}$ \\
\hline C. pi. eth.ac. ext. $5 \%$ & $1.50 \pm 0.50 \mathrm{a}$ & $2.25 \pm 0.63 \mathrm{a}$ & $2.75 \pm 0.48 \mathrm{a}$ & $3.75 \pm 0.25 \mathrm{a}$ & $4.75 \pm 0.25 \mathrm{a}$ \\
\hline C. pi. eth.ac. ext. $2.5 \%$ & $0.50 \pm 0.29 b$ & $1.00 \pm 0.41 \mathrm{~b}$ & $1.75 \pm 0.63 \mathrm{ab}$ & $3.00 \pm 0.48 \mathrm{ab}$ & $3.75 \pm 0.48 \mathrm{ab}$ \\
\hline C. pi. eth.ac. ext. $1.5 \%$ & $0.50 \pm 0.29 b$ & $0.50 \pm 0.29 b c$ & $0.75 \pm 0.25 \mathrm{bcd}$ & $1.25 \pm 0.48 \mathrm{cdef}$ & $1.75 \pm 0.25 \mathrm{def}$ \\
\hline C. pi. meth. ext. $5 \%$ & $0.25 \pm 0.25 b$ & $0.25 \pm 0.25 b c$ & $0.25 \pm 0.25 \mathrm{~cd}$ & $0.50 \pm 0.29 \mathrm{efg}$ & $0.75 \pm 0.48 f g h$ \\
\hline C. pi. meth. ext. $2.5 \%$ & $0.00 \pm 0.00 \mathrm{~b}$ & $0.00 \pm 0.00 \mathrm{c}$ & $0.00 \pm 0.00 \mathrm{~d}$ & $0.00 \pm 0.00 \mathrm{~g}$ & $0.00 \pm 0.00 \mathrm{~h}$ \\
\hline C. pi. meth. ext. $1.25 \%$ & $0.00 \pm 0.00 \mathrm{~b}$ & $0.00 \pm 0.00 \mathrm{c}$ & $0.00 \pm 0.00 \mathrm{~d}$ & $0.00 \pm 0.00 \mathrm{~g}$ & $0.00 \pm 0.00 \mathrm{~h}$ \\
\hline C. pi. water ext. $5 \%$ & $0.50 \pm 0.29 b$ & $0.75 \pm 0.25 b c$ & $1.00 \pm 0.41 \mathrm{bcd}$ & $1.75 \pm 0.25 \mathrm{~cd}$ & $2.00 \pm 0.41 \mathrm{de}$ \\
\hline C. pi. water ext. $2.5 \%$ & $0.50 \pm 0.29 b$ & $1.00 \pm 0.00 \mathrm{~b}$ & $1.00 \pm 0.00 \mathrm{bcd}$ & $1.25 \pm 0.25 \mathrm{cdef}$ & $1.25 \pm 0.25 \mathrm{efg}$ \\
\hline C. pi. water ext. $1.25 \%$ & $0.50 \pm 0.29 b$ & $0.50 \pm 0.29 b c$ & $0.50 \pm 0.29 \mathrm{~cd}$ & $0.50 \pm 0.29 \mathrm{efg}$ & $0.50 \pm 0.29 \mathrm{gh}$ \\
\hline Control & $0.00 \pm 0.00 \mathrm{~b}$ & $0.00 \pm 0.00 \mathrm{c}$ & $0.00 \pm 0.00 \mathrm{~d}$ & $0.00 \pm 0.00 \mathrm{~g}$ & $0.00 \pm 0.00 \mathrm{~h}$ \\
\hline
\end{tabular}

*V. op. $=$ Viburnum opulus; eth. ac. $=$ ethyl acetate; ext. $=$ extract; meth. $=$ methanol; $\mathrm{C}$. pi. $=$ Crataegus pinnatifida

*Values represents mean of four replications with 10 insects each

*Means followed by same letters are not significantly different from each other according to Duncan's test at $\mathrm{P}<0.05$ level 


\section{REPELLENT TEST}

Repellent effect of the studied plant extracts (5\%) against T. castaneum was depicted in Figure 1. Variation results were perceived among the plant extracts against the pest, all extracts of $L$. maackii and $P$. orientalis reflected highly significant repellency compared with the control. However, a majority of $V$. opulus and $C$. pinnatifida extracts showed attractant activities or low repellency effect, except methanol extract of $C$. pinnatifida. The highest repellency percentage was attained by L. maackii (91.38\%), followed by $C$. pinnatifida $(63.07 \%)$. The repellent effect may be due to the presence of the bioactive ingredient in the plants such as monoterpenes and sesquiterpenes.
According to Ilieş et al. (2014), Lonicera spp. contains monoterpenes and sesquiterpenes. Similarly, Gao et al. (2019) isolated monoterpenes from $C$. pinnatifida. These compounds have repellency activity against $T$. castaneum and Rhyzopertha dominica as reported by Garcia et al. (2005) and Ukeh and Umoetok (2011). On the other hand, the methanol extract was the best solvent for repellency effect test. This results agreed with Rehman et al. (2018) who compared repellent effect of four solvents (methanol, chloroform, petroleum ether, and n-hexane) of leaf extracts for three plant extracts, Riciuus communis (L.), Jatropha curcas (L.) and Citrus paradise (Macfad) against $T$. castaneum and observed methanol extracts were more effective than the other solvents.

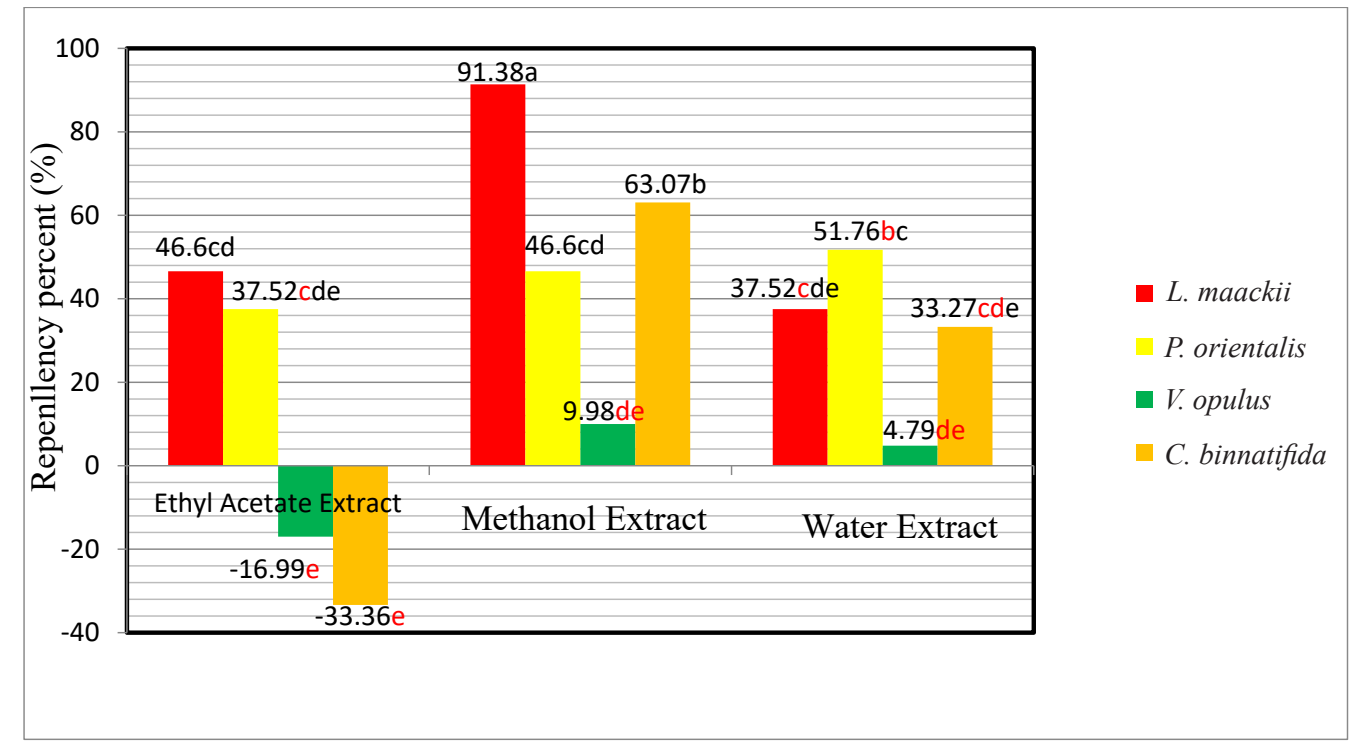

FIGURE 1. Repellency percentages of the studied plant extract (5\%) against the red flour beetle (Tribolium castaneum), during July 2018

*Means followed by same letters are not significantly different from each other according to Tukey's test at $\mathrm{P}<0.05$ level

\section{CONCLUSION}

It is concluded that, some of the biologically active compounds were present in the studied plants. In insecticidal test, the leaves ethyl acetate extracts (5 and
$2.5 \%$ ) of $V$. opulus is the best toxicant treatments against the pest and recommended for additional studies so as to be utilized for pests' control. Moreover, the study proved that the tested extracts of $L$. maackii and P. orientalis 
were very poor mortality effects on the $T$. castaneum, but methanol extracts of both plants scored significantly high repellent activities against the pest. Therefore, studies are also required to prove the presence of antifeedant besides the repellent compounds in L. maackii and P. orientalis leaves extracts and their important in protecting storage grains.

\section{ACKNOWLEDGEMENTS}

This study was sponsored by National Natural Science Foundation of China-Shanxi Joint Funds (Grant No. U1610222), Applied Basic Research Programs of Shanxi Province, China (Grant No.201801D121269). The authors would like to thank the College of Life Sciences, Shanxi University for help us identification of the insect. The authors also appreciate Professor Abdalla Abdelrahim Satti, Environment and Natural Resources Research Institute, Khartoum, Sudan who gave us some advice about this manuscript.

\section{REFERENCES}

Adebayo, A.P., Alad, A.Y. \& Yankubu, O.F. 2017. GC-MS analysis of Viburnum opulus (L.) extract and its toxicity studies in rats. Asian Journal of Pharmaceutical Clinical Research 10(6): 383-388.

Agrafioti, P., Athanassiou, C.G. \& Nayak, M.K. 2019. Detection of phosphine resistance in major stored-product insects in Greece and evaluation of a field resistance test kit. Journal of Stored Products Research 82: 40-47.

Alam, M., Uddin, G., Sadat, A., Muhammd, N., Khan, A.A. \& Siddiqui, B.S. 2012. Evaluation of Viburnum grandiflorum for its in-vitro pharmacological screening. African Journal of Pharmacy and Pharmacology 6(22): 1606-1610.

Alinezhad, S., Kamalzadeh, A., Shams-Ghahfarokhi, M., Rezaee, M.B., Jaimand, K., Kawachi, M., Zamani, Z, Tolouei, R. \& Razzaghi-Abyaneh, M. 2011. Search for novel antifungals from 49 indigenous medicinal plants: Foeniculum vulgare and Platycladus orientalis as strong inhibitors of aflatoxin production by Aspergillus parasiticus. Annals of Microbiology 61(3): 673-681.

Banu, K.S. \& Cathrine, L. 2015. General techniques involved in phytochemical analysis. International Journal of Advanced Research in Chemical Science 2(4): 25-32.

Berndt, W.L. 1963. Synergism in repellent action of combinations of pipernyl butoxide and allethrin. PHD Dissertation. Kansas State University (Unpublished).

Bilal, H., Akram, W., Hassan, S.A., Zia, A., Bhatti A.R., Mastoi, M.I. \& Aslam S. 2015. Insecticidal and repellent potential of citrus essential oils against Tribolium castaneum Herbst (Coleoptera: Tenebrionidae). Pakistan Journal of Zoology 47(4): 997-1002.
Castillo-Sánchez, L.E., Jiménez-Osornio, J.J. \& Delgado-Herrera, M.A. 2010. Secondary metabolites of the annonaceae, solanaceae and meliaceae families used as biological control of insects. Tropical and Subtropical Agroecosystems 12: 445-462.

Chen, X., Zhang, S., Xuan, Z., Ge, D., Chen X., Zhang, J., Wang, Q., Wu, Y. \& Liu, B. 2017. The phenolic fraction of Mentha haplocalyx and its constituent Linarin ameliorate inflammatory response through inactivation of NF- $\mathrm{KB}$ and MAPKs in lipopolysaccharide-induced RAW264.7 cells. Molecules 22(5): 811.

Chu, W., Gao, P. \& Li, L.Z. 2019. Chemical constituents from the leaves of Crataegus pinnatifida Bge. Biochemical Systematics and Ecology 86: 103923.

Cipollini, D., Stevenson, R., Enright, S., Eyles, A. \& Bonello, P. 2008. Phenolic metabolites in leaves of the invasive shrub, Lonicera maackii, and their potential phytotoxic and anti-herbivore effects. Journal of Chemical Ecology 34: 144-152.

Dhaniya, M.V. \& Dayanandan, S. 2016. Common medicinal plants as repellents against stored grain insects Sitophilus oryzae and Tribolium castaneum. Journal of Agriculture and Veterinary Science 9(8): 71-77.

Dorning, M. \& Cipollini, D. 2006. Leaf and root extracts of the invasive shrub, Lonicera maackii, inhibit seed germination of three herbs with no autotoxic effects. Plant Ecology 184(2): 287-296.

Duhan, J.S., Saharan, P., Surekha \& Kumar, A. 2013. Antimicrobial potential of various fractions of Thuja orientalis. African Journal of Microbiology Research 7(25): 3179-3186.

Dwivedi, S.C. \& Shekhawat, N.B. 2004. Repellent effect of some indigenous plant extracts against Trogoderma granarium (everts). Asian Journal of Experimental Sciences $18(1 \& 2): 47-51$

Ebadollahi, A. 2011. Chemical constituents and toxicity of Agastache foeniculum (pursh) kuntze essential oil against two stored-product insect pests. Chilean Journal of Agricultural Research 71(2): 212-217.

Elamin, M.M. \& Satti, A.A. 2013. Insecticidal potentialities of Balanites aegyptiaca extracts against the khapra beetle (Trogoderma granarium). Global Advanced Research Journal of Environmental Science and Toxicology 2(1): 5-10.

Elamin, M.M. \& Satti, A.A. 2012. Insecticidal and repellent effects of Aristolochia bracteolata lam. against Trogoderma granarium everts. International Journal of Science Innovations and Discoveries 2(6): 559-566.

E1 Minshawy, A.M. \& Hegazi, E.M. 2001. Insect Pests and Animal and Their Control. 1st edition. Alexandria, Egypt: Modern Almaarif Library.

Emery, R. \& Cousins, D. 2019. Insect Pests of Stored Grain. https://www.agric.wa.gov.au/print/node/1167. Accessed on 24 May 2019. 
Gao, P., Li, S., Liu, K., Sun, C., Song, S. \& Li, L. 2019. Antiplatelet aggregation and antithrombotic benefits of terpenes and flavones from hawthorn leaf extract isolated using the activity-guided method. Food and Function 10(2): 859-866.

Gao, P.Y., Li, L.Z., Peng, Y., Li, F.F., Niu, C., Huang, X.X. \& Song, S.J. 2010. Monoterpene and lignan glycosides in the leaves of Crataegus pinnatifida. Biochemical Systematics and Ecology 38(5): 988-992.

Garcia, M., Donadel, O.J., Ardanaz, C.E., Tonn, C.E. \& Sosa, M.E. 2005. Toxic and repellent effects of Baccharis salicifolia essential oil on Tribolium castaneum. Pest Management Science 61: 612-618.

Ilieş, D.C., Rădulescu, V. \& Duţu, L. 2014. Volatile constituents from the flowers of two species of honeysuckle (Lonicera japonica and Lonicera caprifolium). Farmacia 62(1): 194201.

Jasuja, N.D., Sharma, S.K., Saxena, R., Choudhary, J., Sharma, R. \& Joshi, S.C. 2013. Antibacterial, antioxidant and phytochemical investigation of Thuja orientalis leaves. Journal of Medicinal Plants Research 7(25): 1886-1893.

Kumar, G.S., Jayaveera, K.N., Kumar, C.K.A., Sanjay, U.P., Swamy, B.M.V. \& Kumar, D.V.K. 2007. Antimicrobial effects of Indian medicinal plants against acne-inducing bacteria. Tropical Journal of Pharmaceutical Research 6(2): 717-723.

Leonard, J.E. \& Ehrman, L. 1976. Recognition and sexual selection in Drosophila: Classification, quantification and identification. Science 193(4254): 693-695.

Manimegalai, S., Adhithya, R., Vellaikumar, S., Paramasivam, M. \& Chandrasekaran, S. 2010. Separation and characterization of antibacterial compounds from Aegle marmelos correa and Thuja orientalis L. against silkworm pathogens. International Journal of Genetic Engineering and Biotechnology 1(3): 177-186.

Meyer, J.R. 2020. General Entomology: Coleoptera. https:// projects.ncsu.edu/cals/course/ent425/library/compendium/ coleoptera.html. Accessed on January 2020.

Miller, K.E. \& Gorchov, D.L. 2004. The invasive shrub, Lonicera maackii, reduces growth and fecundity of perennial forest herbs. Oecologia 139(3): 359-375.

Mishra, B.B., Tripathi, S.P. \& Tripathi, C.P.M. 2016. Effect of temperature at fixed relative humidity in fecundity and development of Tribolium castaneum (herbst). Journal of Entomology and Zoology Studies 4(3): 255-257.

Nayak, M.K. \& Daglish, G.J. 2018. Importance of stored product insects. In Recent Advances in Stored Product Protection, edited by Athanassiou, C. \& Arthur, F. Berlin: Springer. pp. 1-17.

Noling, J.W. \& Becker, J.O. 1994. The challenge of research and extension to define and implement alternative to methyl bromide. Journal of Nematology 26(45): 573-586.

Parekh, J. \& Chanda, S.V. 2007. In vitro antimicrobial activity and phytochemical analysis of some Indian medicinal plants. Turkish Journal of Biology 31(1): 53-58.
Priya, A., Trupti, S. \& Mira, R. 2016. Insecticidal activity of different solvent extracts of Zanthoxylum rhetsa (ROXB.) DC. against Tribolium castaneum herbst. World Journal of Pharmaceutical and Life Sciences 2(4): 230-239.

Regnault-Roger, C., Ribodeau, M., Hamraoui, A., Bareau, I., Blanchard, P., Gil-Munoz, M.I. \& Barberan, F.T. 2004. Polyphenolic compounds of Mediterranean Lamiaceae and investigation of orientational effects on Acanthoscelides obtectus (say). Journal of Stored Products Research 40: 395-408.

Rehman, H., Mirza, S., Hasan M., Ali, Q., Shakir, H.A. \& Yasir, M. 2018. Repellent potential of three medicinal plant extracts against Tribolium castaneum (Coleoptera: Tenebrionidae). Punjab University Journal of Zoology 33(2): 121-126.

Sallam, M.N. 1999. Insect damage: Post-harvest operation. InInformation on Post-harvest Operations (INHpO), edited by Mejía, D. Nairobi, Kenya. pp. 12-13.

Sasidharan, S., Chen, Y., Saravanan, D., Sundram, K.M. \& Latha, L.Y. 2011. Extraction, isolation and characterization of bioactive compounds plants' extracts. African Journal of Traditional Complementary and Alternative Medicines 8(1): 1-10.

Sati, S.C., Joshi, S. \& Kumar, P. 2014. Antibacterial activity of Kumaun Himalayan Biota orientalis L. leaf extracts. African Journal of Microbiology Research 8(6): $603-$ 608.

Satti, A.A. \& Elamin, M.M. 2012. Insecticidal activities of two meliaceous plants against Trogoderma granarium everts (Coleoptera: Dermestidae). International Journal of Science and Nature 3(3): 696-701.

Selvakumar, S. \& Madhan, K.U. 2017. Preliminary phytochemical analysis of various extracts of Croton bonplandianus. Research Journal of Pharmaceutical, Biological and Chemical Sciences 8(3): 173.

Seufi, A.M. \& Galal, F.H. 2019. Insects as medical suppliers of bioreactors: Mini review. Journal of Innovative Science and Technology 1(1): 1-9.

Shaheen, F.A., Parveen, S., Zia, A., Qadir, G., Husain, M. \& Khan, R.U. 2016. Predatory aptness of ants against red flour beetle, Tribolium castaneum herbst (Tenebrionidae: Coleoptera) in wheat flour. Pakistan Journal of Agricultural Sciences 29(2): 170-178.

Shi, L., Yang, X., Gao, Z., Jia, Y., Bi, Z., Lu, F. \& Cui, T. 2018. Determination of nine phenolic components in leaves of Crataegus pinnatifida Bge. Medicinal Plant 9(2): 22-26.

Song, S.J., Li, L.Z., Gao, P.Y., Peng, Y., Yang, J.Y. \& Wu, C.F. 2011. Terpenoids and hexenes from the leaves of Crataegus pinnatifida. Food Chemistry 129(3): 933-939.

Taylor, R.W.D. 1994. Methyl bromide: Is there any future for this fumigant? Journal of Stored Products Research 30(4): 253-260.

Ukeh, D.A. \& Umoetok, S.B.A. 2011. Repellent effects of five monoterpenoid odours against Tribolium castaneum (herbst) and Rhyzopertha dominica (F.) in Calabar, Nigeria. Crop Protection 30(10): 1351-1355. 
Via, S. 1999. Cannibalism facilitates the use of a novel environment in the flour beetle, Tribolium castaneum. Heredity 82: 267-275.

Waliullah, T.M., Yeasmin, A.M., Wahedul, M. \& Parvez, H. 2014. Insecticidal and repellent activity of Clerodendrum viscosum vent. (Verbenaceae) against Tribolium castaneum (herbst) (Coleoptera: Tenebrionoidea). Academic Journal of Entomology 7(2): 63-69.

Wen, L., Lin, Y., Lv, R., Yu, J., Zhao, H., Wang, X. \& Wang, D. 2017. An efficient method for the preparative isolation and purification of flavonoids from leaves of Crataegus pinnatifida by HSCCC and Pre-HPLC. Molecules 22(5): 767.

White, N.D.G. 1995. Insects, mites and insecticides in stored grain ecosystems. In Stored Grain Ecosystems, edited by Jayas, D.S., White, N.D.G. \& Muir, W.E. New York: Marcel Dekker Inc. pp. 123-168.

World Health Organization (WHO). 1997. Medicinal Plants in China: A Selection of 150 Commonly Used Species. Manila: WHO Regional Office for the Western Pacific.

Wu, J., Peng, W., Qin, R.Z. \& Zhou, H. 2014. Crataegus pinnatifida: Chemical constituents, pharmacology, and potential applications. Molecules 19(2): 1685-1712.

Zettler, L.C. \& Cuperus, G.W. 1990. Pesticide resistance in Tribolium castaneum (Coleoptera: Tenebrionidae) and Rhyzopertha dominica (Coleoptera: Bostrichidae) in wheat. Journal of Economic Entomology 83(5): 1677-1681.
Zia, A., Aslam, M., Naz, F.I. \& Illyas, M. 2011. Bio-efficacy of some plant extracts against chickpea beetle, Callosobruchus chinensis linnaeus (Coleoptera: Bruchidae) attacking chickpea. Pakistan Journal of Zoology 43(4): 733-737.

Mokhtar Mohamedalamin Mokhtar, Jianfeng Li, Zhiping Du \& Fangqin Cheng*

Institute of Resources and Environmental Engineering

Shanxi University

Taiyuan, Shanxi 030006

China

Mokhtar Mohamedalamin Mokhtar

General Plant Protection and Biological Control Directorate Ministry of Agriculture

Animal Resources and Irrigation

Khartoum State, Khartoum 11111

Sudan

*Corresponding author; email: cfangqin@sxu.edu.cn

Received: 28 June 2020

Accepted: 10 December 2020 